\title{
Effects of gastric surgery upon gastric emptying in cases of peptic ulceration
}

\author{
K. G. BUCKLER \\ From the Royal Infirmary, Bristol
}

EDITORIAL COMMENT Attention is drawn to the considerable gastric stasis which is associated with vagotomy plus drainage operations.

\begin{abstract}
Alteration in the rate of gastric emptying has long been considered responsible for many of the sequelae of gastric surgery. For example, rapid gastric emptying after gastroenterostomy (Hertz, 1913; Mix, 1922) or Polya gastrectomy (Johnson, 1954; Abbott, Krieger, and Levey, 1958) can cause one type of 'dumping syndrome'. Delayed post-gastrectomy emptying may also cause problems (Snell, 1937; Hosford, 1949). Dragstedt treated duodenal ulcers with vagotomy, but the resulting gastric stasis was associated with a high incidence of gastric ulceration (Dragstedt, Camp, and Fritz, 1949). It was this observation that led them to believe that almost all gastric ulcers were caused by antral overactivity associated with gastric stasis.

Several workers have studied gastric emptying in the early post-operative period using either radiological (Abbott et al., 1958; Rothnie, Harper, and Catchpole, 1963; Well's Tinckler, Rawlinson, Jones, and Saunders, 1964) or pressure balloon (Goodall, 1964) records. However, the late effects of gastric surgery on gastric emptying have been rarely studied (Roth, Vilardell, and Affolter, 1962; Butler, 1964; Goodall, 1966). This work was carried out in an attempt to correct this deficiency in our knowledge, and also to test the validity of the theory that gastric stasis causes gastric ulceration.
\end{abstract}

\section{ASSESSMENT OF GASTRIC EMPTYING}

The clinical criteria upon which a diagnosis of pyloric stenosis is made are well known (Balint and Spence, 1959), but the signs and symptoms of gastric stasis are less certain (Roth et al., 1962; Hildebrand and Thomson, 1964).

Radiological estimations of gastric emptying are often inaccurate as fluid barium fails to reproduce the effects of solid food (Emery and Monroe, 1931;
Van Liere and Sleeth, 1940). Similarly barium sulphate mixed with solid food, as in the Edwald meal (Sun, Shay, and Woloshin, 1959), may become separated from the food in the stomach or even irritate the gastric mucosa. Horton, Ross, and Darling (1965) added enteric-coated barium sulphate granules instead of liquid barium to food to overcome these difficulties. Their method allows an easier radiological estimation of the rate at which the meal leaves the stomach, although it fails to give any idea of the amount of gastric secretions being added.

External scanning of the stomach after giving a meal containing radioactive isotopes is a new technique, but its use is limited to certain centres, and also possibly to the exclusion of certain cases (Griffith, Owen, Kirkman, and Shields, 1966).

The fractional test meal method, with its wide variation of suggested indicators (Hunt, 1959), is limited to liquids, or, at best, semi-solids. Only the final end-point can be discovered, and as the rate of gastric emptying is very slow terminally (Hunt and Spurrell, 1951), the figure obtained may be a misleading index of gastric evacuation.

A better method of examining gastric emptying and gastric secretion is by the serial test meal (de Salamanca, 1943; Hunt and Spurrell, 1951). This allows a study of the rate at which the stomach empties, but presupposes that a particular stomach empties a standard meal in a similar way on successive occasions.

The criteria for the choice of meal eaten have been clearly defined (Hunt and Spurrell, 1951), but the physical state of the food is also important (Silverio, 1964). Too often, the cooperation and position of the patient are ignored, yet both are important (Todd and Kuenzel, 1929; Rothnie et al., 1963).

Definition is also required as to when the stomach 
is empty. Since food leaves the stomach at an exponential rate, the 'half-life' of the meal is the best criterion (Hunt and Spurrell, 1951; Griffith et al., 1966). In fractional test meals the only end-point detectable is when the stomach is completely empty, and it is at this point that the meal can definitely no longer stimulate the gastric antrum.

\section{METHODS}

METHOD I The patient, who was allowed a cup of tea not less than two hours before the test, swallowed a no. 14-16 F.G. nasogastric tube. In the early part of the study the radio-opaque tip of the tube was screened into the lowest part of the stomach, but later it was found more accurate to judge the tip of the tube's position by the nature of the aspirate. After emptying the stomach completely, a standard meal was given. This consisted of two scoops of mashed potato $(150 \mathrm{~g}$.) to which a little starch powder $(10-15 \mathrm{~g}$.) had been added. Up to $15 \mathrm{ml}$. Marmite gravy and salt were added if desired. After one hour, $5 \mathrm{ml}$. of gastric content was aspirated, and this sample was tested for starch and sugar, the $p \mathrm{H}$ and the presence of bile, blood, and mucus being noted. Water, $2 \mathrm{ml}$., was then flushed down the tube. Depending on the concentration of starch in the aspirate, a further sample was taken after quarter, half, or one hour, the frequency of testing increasing as concentration fell. When starch was found to be absent on more than two consecutive occasions, the patient drank half a cupful of water and the stomach was again emptied. This gastric lavage was also tested for starch, and if any was present, the test result was not included in the series. If gastric digestion of starch was found to have occurred, as evidenced by more than a trace of sugar being present, the result was likewise excluded from the series. The end-point was taken as the time when starch was last found in the gastric aspirate, and on the trial series of normal control patients and students the test was found to be reproducible to within one hour from day to day.

In some cases, particularly following operation, however, difficulty was encountered in determining the end-point, due to the tendency for the aspirating tip to migrate out of the stomach. Nor were we certain that the presence of a nasogastric tube was not in itself interfering with gastric emptying.

METHOD II In this test no tube was passed. The patient had nothing by mouth for at least 12 hours before the test except for a cup of tea not less than two hours before eating the standard meal. The meal consisted of two scoops of mashed potato (as in method I) to which was added half a scoop of enteric-coated barium granules (35 g.). Marmite gravy and salt were added as requested. The patient was then radiographed two hours after eating the meal, and again at hourly or two-hourly intervals until the stomach was shown to be radiologically empty. In a small series of cases, gastric lavage just before and just after the radiologically judged end-point showed that the potato and the granules disappeared from the stomach at the same point.
Comparing these two methods on a series of patients showed that the results were as close as could be expected allowing for daily variation, despite the fact that in method II the stomach was not emptied before giving the meal.

Many out-patients who were tested were unable to remain at the hospital more than six or eight hours (because of other commitments), so in these cases an estimate was made of the amount of meal remaining in the stomach. Results were expressed as ' $6++$ hours, if the stomach was found to contain more than $25 \%$ of the original meal at six hours, or if the final emptying time was more than eight hours after taking the meal. If less than $25 \%$ of the original meal remained at six hours, or if the stomach emptied between six and eight hours, ' $6+$ hours' was recorded as the gastric emptying time. Frequently prolonging the test for more than six hours caused the patient to become acutely hungry, even if half the meal remained in the stomach.

\section{MATERIAL}

The normal gastric emptying times were calculated for a group of 69 medical students and 81 patients who had no sign or symptom of alimentary disease. Pre-operative studies were made on 280 patients with gastroduodenal ulcers. Two hundred and thirty-nine patients had emptying times performed at periods of over one year after various forms of gastric surgery.

In 35 normal cases, 125 ulcer patients, and 182 postoperative cases studied radiologically, estimations were made of the amount of food remaining in the stomach at two, four, and six hours after the meal was eaten. The means and standard deviations in each clinical group were then calculated (Tables IV and V).

\section{RESULTS}

Since the results of methods I and II are comparable, in individual cases (Fig. 1), they have been combined.

NORMAL PATIENTS Table I shows the results. In patients under 60 years of age the stomach is found to be completely empty in more than $75 \%$ of cases between two and six hours. In the older age group, there is a general tendency towards slower gastric emptying. Where a hiatus hernia is present, without an associated ulcer, the pattern is similar. But in patients with pernicious anaemia and achlorhydria the gastric emptying time is markedly shortened.

DUODENAL ULCER In these patients, the overall pattern is similar to that seen in the normal population (Table II). The longer emptying times tend to be found in patients with the most marked hypersecretion and the longest history.

GASTRIC ULCER Table II also shows the results for gastric ulcer. Johnson, Love, Rogers, and Wyatt 


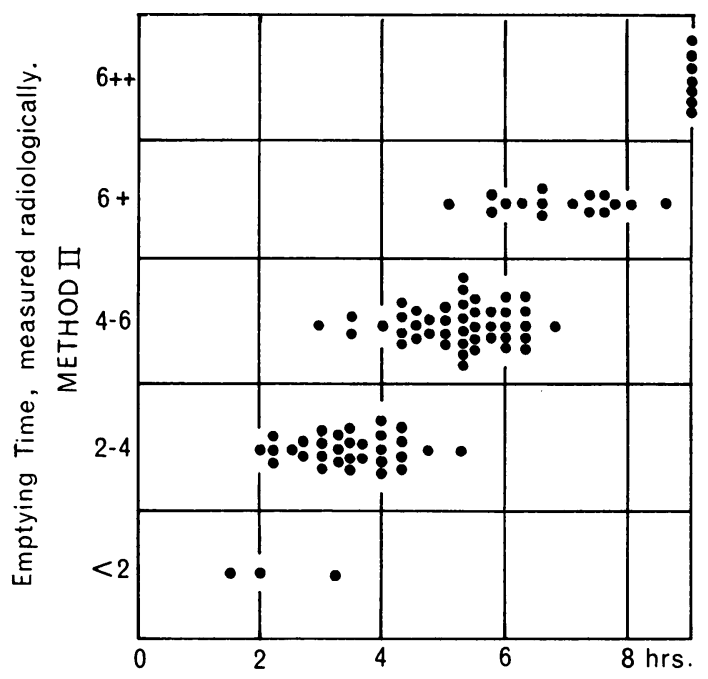

Emptying Time, measured by tube. METHOD I

FIG. 1. Comparisons of methods of measuring gastric emptying in 100 cases.
(1964) group patients with gastric ulcer into three types. No evidence of gross stasis was found in any stomachs of patients with gastric ulcers, whether the ulcers were pre-pyloric or on the lesser curve, or whether an associated pyloro-duodenal deformity was present or not. The only gastric ulcer patients with prolonged emptying times are those in whom gross scarring of the lesser curve has occurred, producing a tea- or coffee-pot deformity: this is particularly common in uncomplicated gastric ulcers with no associated pyloro-duodenal abnormality.

MALIGNANT GASTRIC ULCERS Although only a few cases were studied, in those with malignant ulcers there was a marked tendency to gastric stasis, even when, as in two patients, the malignancy was confined to an area $0.2 \mathrm{~cm}$. in diameter in the edge of a chronic benign ulcer, not obstructing or involving the pylorus.

POST-OPERATIVE FINDINGS Table III sets out the results for all operations studied

TABLE I

TIME OF COMPLETE GASTRIC EMPTYING IN NORMAL CASES

No. of Cases Time in Hours after Meal

Studied

\begin{tabular}{lllll}
\hline Less than 2 & $2-4$ & $4-6$ & $6+$ & $6++$ \\
\hline No. & No. & No. & No. & No.
\end{tabular}

\begin{tabular}{|c|c|c|c|c|c|c|}
\hline Total & 150 & $5(3.3 \%)$ & $44(29 \cdot 3 \%)$ & $80(53 \cdot 3 \%)$ & $18(12 \%)$ & $3(2 \%)$ \\
\hline Male & 106 & $2(1.9 \%)$ & $35(33.0 \%)$ & $57(53.7 \%)$ & $11(10.4 \%)$ & $1(0.9 \%)$ \\
\hline Female & 44 & $3(6 \cdot 8 \%)$ & $9(20.4 \%)$ & $23(52.4 \%)$ & $7(15.9 \%)$ & $2(4 \cdot 5 \%)$ \\
\hline \multicolumn{7}{|l|}{ Age } \\
\hline Less than 20 years & 32 & $-\quad-$ & $9(28 \cdot 1 \%)$ & $19(59 \cdot 4 \%)$ & $4(12.5 \%)$ & - \\
\hline $21-30$ years & 46 & -- & $11(23.9 \%)$ & $32(69 \cdot 6 \%)$ & $1(2.2 \%)$ & $2(4 \cdot 3 \%)$ \\
\hline $31-40$ years & 14 & -- & $4(28.6 \%)$ & $7(50 \%)$ & $3(21.4 \%)$ & $-\quad-$ \\
\hline 41-50 years & 21 & $3(14 \cdot 3 \%)$ & $7(33.3 \%)$ & $9(42.8 \%)$ & $2(9 \cdot 5 \%)$ & - \\
\hline $51-60$ years & 17 & $-\quad-$ & $7(41.2 \%)$ & $6(35.2 \%)$ & $3(17.6 \%)$ & $1(5.9 \%)$ \\
\hline $61-70$ years & 10 & $2(20 \%)$ & $2(20 \%)$ & $2(20 \%)$ & $4(40 \%)$ & -- \\
\hline Over 70 years & 10 & -- & $4(40 \%)$ & $5(50 \%)$ & $1(10 \%)$ & $-\quad-$ \\
\hline
\end{tabular}

TABLE II

TIME OF COMPLETE GASTRIC EMPTYING IN PRE-OPERATIVE CASES

\begin{tabular}{|c|c|c|c|c|c|c|}
\hline \multirow[t]{3}{*}{ Diagnosis } & \multirow{3}{*}{$\begin{array}{l}\text { No. of Cases } \\
\text { Studied }\end{array}$} & \multicolumn{5}{|c|}{ Time in Hours after Meals } \\
\hline & & Less than 2 & $2-4$ & $4-6$ & $6+$ & $6++$ \\
\hline & & No. & No. & No. & No. & No. \\
\hline Hiatus hernia & 12 & $2(16 \cdot 7 \%)$ & $3(25 \%)$ & $4(33 \cdot 3 \%)$ & $2(16 \cdot 7 \%)$ & $1(8.3 \%)$ \\
\hline Pernicious anaemia & 24 & $12(50 \%)$ & $9(37.5 \%)$ & $3(12.5 \%)$ & $-\quad-$ & -1 \\
\hline Duodenal ulcer & 193 & $4(2.1 \%)$ & $59(30.5 \%)$ & $72(37 \cdot 3 \%)$ & $41(21 \cdot 3 \%)$ & $17(8.8 \%)$ \\
\hline Gastric ulcer (total) & 83 & $3(3.6 \%)$ & $19(23.1 \%)$ & $31(37.4 \%)$ & $24(28.9 \%)$ & $6(7.2 \%)$ \\
\hline Type I & 40 & $-\quad-$ & $9(22.5 \%)$ & $14(35 \%)$ & $14(35 \%)$ & $3(7.5 \%)$ \\
\hline Type II & 18 & $1 \quad(5.6 \%)$ & $4(22.2 \%)$ & $8(44.4 \%)$ & $4(22 \cdot 1 \%)$ & $1(5.6 \%)$ \\
\hline Type III & 25 & $2(8 \%)$ & $6(24 \%)$ & $9(36 \%)$ & $6(24 \%)$ & $2(8 \%)$ \\
\hline Gastric carcinoma & 14 & -107 & $2(14 \cdot 3 \%)$ & $2(14 \cdot 3 \%)$ & $1(7 \cdot 1 \%)$ & $9(64 \cdot 3 \%)$ \\
\hline
\end{tabular}


TABLE III

TIME OF COMPLETE GASTRIC EMPTYING IN POST-OPERATIVE CASES

\begin{tabular}{|c|c|c|c|c|c|c|}
\hline \multirow[t]{3}{*}{ Operation } & \multirow{3}{*}{$\begin{array}{l}\text { No. of Cases } \\
\text { Studied }\end{array}$} & \multicolumn{5}{|c|}{ Time in Hours after Meals } \\
\hline & & Less than 2 & $2-4$ & $4-6$ & $6+$ & $6++$ \\
\hline & & No. & No. & No. & No. & No. \\
\hline Polya & 45 & $11(24.4 \%)$ & $26(57.8 \%)$ & $7(15 \cdot 5 \%)$ & $1(2 \cdot 2 \%)$ & - \\
\hline Billroth I & 41 & $2(4.9 \%)$ & $18(43.9 \%)$ & $17(41.5 \%)$ & $4(9.8 \%)$ & - \\
\hline Pyloroplasty & 8 & $1^{1}(12 \cdot 5 \%)$ & $-\quad-$ & $3(37.5 \%)$ & $3(37.5 \%)$ & $1(12 \cdot 5 \%)$ \\
\hline Gastroenterostomy & 9 & $-\quad-$ & $4(44.5 \%)$ & $4(44.5 \%)$ & $1(11 \cdot 1 \%)$ & $-\quad-$ \\
\hline Vagotomy & 15 & $-\quad-$ & $-\quad-$ & $-\quad-$ & $6(40 \%)$ & $9(60 \%)$ \\
\hline Vagotomy + Polya & 22 & $2(9,1 \%)$ & $6(27,2 \%)$ & $4(18,2 \%)$ & $4(18,2 \%$ & $6(27,2 \%)$ \\
\hline Vagotomy + Billroth I & 27 & $-\quad-$ & $4(14.8 \%)$ & $3(11 \cdot 1 \%)$ & $5(18.5 \%)$ & $15(55.6 \%)$ \\
\hline Vagotomy + pyloroplasty & 35 & $-\quad-$ & $-\quad-$ & $4(11.4 \%)$ & $11(31.4 \%)$ & $20(57.2 \%)$ \\
\hline Vagotomy + gastroenterostomy & 37 & $-\quad-$ & $3(8 \cdot 1 \%)$ & $8(21.6 \%)$ & $22(59 \cdot 5 \%)$ & $4(10.8 \%)$ \\
\hline
\end{tabular}

Gastrectomy Gastric resection undoubtedly speeds the rate at which a meal leaves the stomach. This rapid emptying time is more frequent with a Polya than with a Billroth I anastomosis (Johnson, 1954).

Gastroenterostomy Gastric emptying was only delayed in one case, where the stoma was high in the body. In all the low antral anastomoses, gastric emptying proceeded at a normal or increased rate.

Pyloroplasty or pylorectomy In the small series we have studied, the only case where this operation hastened gastric emptying was in a woman with pernicious anaemia, in whom an operation was performed for adult hypertrophic pyloric stenosis. In all other cases, gastric emptying was if anything slightly delayed, the operation having been performed either after a duodenotomy or distal to a benign gastric ulcer.

Vagotomy alone If vagotomy is performed alone, gastric stasis invariably results.

Vagotomy and antrectomy Vagotomy delays gastric emptying in almost all cases, particularly where gastric resection was limited and where a gastroduodenal anastomosis was employed.

Vagotomy and gastroenterostomy When gastroenterostomy is used as a 'drainage' operation after vagotomy, there is a considerable range of emptying times, probably reflecting the wide variety of different anastomoses employed. Stasis is still common, and if absent, delay is often found distal to the anastomosis.

Vagotomy and pyloroplasty In our experience, when either total or selective vagotomy is combined with pyloroplasty, greater delay is found in gastric emptying than following any other gastric operation. Nor does the type of vagotomy or variety of pyloroplasty or pylorectomy cause any significant difference.

\section{DISCUSSION}

The mechanism by which the stomach empties has been described frequently (Thomas, 1957; Hunt, 1959). It depends normally on the integrity of the antro-pyloro-duodenal pump. The pylorus is open most of the time, closing only as a peristaltic wave passes through it to prevent regurgitation of duodenal contents into the stomach during duodenal cap systole (Johnson, 1961). Gastric emptying must depend on a pressure gradient existing between the stomach and duodenum.

One of the main inhibitory factors controlling gastric emptying is the acidity of the chyme entering the duodenum. In normal patients (Shay and Gershon-Cohen, 1934) adding acid to a meal delays emptying. We found the fastest emptying stomachs in patients with achlorhydria with or without pernicious anaemia. The greater scatter seen in the older age groups of the control series (Table I) may be explained by an increased tendency to achlorhydria with rapid emptying on the one hand, and asymptomatic gastric stasis on the other, such as in the man aged 60 with gastric stasis who, having had 22 pain-free haematemeses in 25 years, reluctantly agreed to being investigated but absolutely refused all forms of treatment.

Hunt (1957) has shown that, even when ulcerated, the duodenum retains sensitivity to acid in the chyme, and, we noted, in duodenal ulcer patients, slowly emptying stomachs tended to be associated with high acid production, whether assessed by the 12-hour night secretion test or the augmented histamine test (Tables IX and X). Yet some maintain that in duodenal ulcer patients the stomach is rapidly emptied (Griffith et al., 1966). A possible explanation for this apparent discrepancy may be afforded by the inclusion or exclusion of cases of 
TABLE IV

VOLUME OF NIGHT SECRETION IN CASES OF DUODENAL ULCER

\begin{tabular}{lrrrr}
$\begin{array}{l}\text { Emptying } \\
\text { Time }(\mathrm{hr} .)\end{array}$ & $\begin{array}{l}\text { No. of } \\
\text { Cases }\end{array}$ & \multicolumn{2}{l}{$\begin{array}{l}\text { Volume of Night Secretion in Duodenal } \\
\text { Ulcer Patients }(\mathrm{ml} .)\end{array}$} \\
\cline { 3 - 5 } & & Range & Mean & $\begin{array}{c}\text { Standard } \\
\text { Deviation }\end{array}$ \\
\hline $2-4$ & 18 & $210-1,213$ & 572 & 297 \\
$4-6$ & 24 & $270-1,696$ & 662 & 288 \\
$6+$ & 15 & $590-1,867$ & 1,168 & 379 \\
$6++$ & 7 & $676-2,255$ & 1,117 & 597
\end{tabular}

TABLE V

AUGMENTED HISTAMINE RESPONSE IN CASES OF DUODENAL ULCER

\begin{tabular}{lcccc}
$\begin{array}{l}\text { Emptying } \\
\text { Time }(\mathrm{hr} .)\end{array}$ & $\begin{array}{c}\text { No. of } \\
\text { Cases }\end{array}$ & \multicolumn{2}{c}{$\begin{array}{l}\text { Augmented Histamine Response in } \\
\text { Duodenal Ulcer Patients }(\mathrm{mEq} . \text { free } \mathrm{HCl})\end{array}$} \\
\cline { 2 - 5 } & & Range & Mean & $\begin{array}{c}\text { Standard } \\
\text { Deviation }\end{array}$ \\
\hline $2-4$ & 34 & $0 \cdot 6-44$ & $19 \cdot 8$ & 11.9 \\
$4-6$ & 35 & $9-40 \cdot 5$ & $25 \cdot 2$ & $7 \cdot 7$ \\
$6+$ & 22 & $22-47 \cdot 6$ & $33 \cdot 7$ & $7 \cdot 7$ \\
$6++$ & 11 & $1 \cdot 0-59$ & 24.6 & 17.8
\end{tabular}

TABLE IVa

PERCENTAGE OF MEAL REMAINING IN STOMACH

\begin{tabular}{|c|c|c|c|c|c|c|c|}
\hline \multirow[t]{3}{*}{ Pre-operative Diagnosis } & \multirow{3}{*}{$\begin{array}{l}\text { No. of Cases } \\
\text { Studied }\end{array}$} & \multicolumn{6}{|c|}{ Time after Meal } \\
\hline & & \multicolumn{2}{|c|}{ Two Hours } & \multicolumn{2}{|c|}{ Four Hours } & \multicolumn{2}{|c|}{ Six Hours } \\
\hline & & Mean & $\begin{array}{l}\text { Standard } \\
\text { Deviation }\end{array}$ & Mean & $\begin{array}{l}\text { Standard } \\
\text { Deviation }\end{array}$ & Mean & $\begin{array}{l}\text { Standard } \\
\text { Deviation }\end{array}$ \\
\hline Normal & 35 & $34 \cdot 7$ & $22 \cdot 6$ & $8 \cdot 1$ & 11.9 & 1.9 & $5 \cdot 1$ \\
\hline Hiatus heria & 6 & $22 \cdot 5$ & 26 & $2 \cdot 2$ & 3.9 & - & - \\
\hline Pernicious anaemia & 4 & 10 & $9 \cdot 1$ & - & - & - & - \\
\hline Duodenal ulcer & 75 & $42 \cdot 4$ & $8 \cdot 0$ & $15 \cdot 5$ & $22 \cdot 4$ & $8 \cdot 3$ & $19 \cdot 3$ \\
\hline \multicolumn{8}{|l|}{ Gastric ulcer } \\
\hline Type I & 24 & $44 \cdot 1$ & $23 \cdot 3$ & $21 \cdot 8$ & $23 \cdot 6$ & $5 \cdot 6$ & $8 \cdot 5$ \\
\hline Type II & 11 & $29 \cdot 1$ & $17 \cdot 6$ & 8.9 & $8 \cdot 4$ & 2.9 & $4 \cdot 6$ \\
\hline Type III & 9 & $34 \cdot 4$ & $30 \cdot 6$ & $17 \cdot 8$ & $19 \cdot 6$ & $10 \cdot 9$ & $24 \cdot 6$ \\
\hline Gastric carcinoma & 6 & 50 & $28 \cdot 6$ & $35 \cdot 8$ & $30 \cdot 2$ & $31 \cdot 2$ & $35 \cdot 4$ \\
\hline
\end{tabular}

TABLE Va

PERCENTAGE OF MEAL REMAINING IN STOMACH

Post-operative Diagnosis

No. of Cases Time after Meal

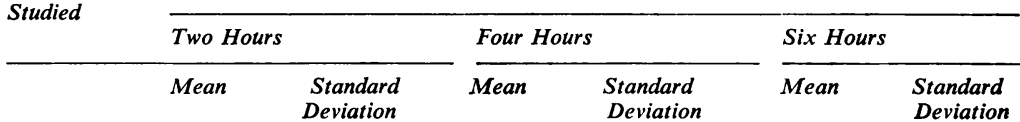

Polya

Billroth I

Pyloroplasty

Gastroenterostomy

Vagotomy alone

Vagotomy + Polya

Vagotomy + Billroth I

Vagotomy + pyloroplasty

Vagotomy + gastroenterostomy

$\begin{array}{rrrrrrr}33 & 6 \cdot 3 & 8 \cdot 7 & 0 \cdot 6 & 2 \cdot 3 & 0 \cdot 1 & 0 \cdot 4 \\ 29 & 12 \cdot 3 & 12 \cdot 0 & 3 \cdot 1 & 7 \cdot 9 & 1 \cdot 3 & 4 \cdot 9 \\ 7 & 47 \cdot 1 & 11 \cdot 2 & 22 \cdot 1 & 19 \cdot 5 & 13 \cdot 6 & 15 \cdot 2 \\ 8 & 17 \cdot 5 & 14 \cdot 1 & 5 \cdot 8 & 8 \cdot 2 & - & - \\ 14 & 84 \cdot 6 & 22 \cdot 5 & 71 \cdot 8 & 30 \cdot 8 & 47 \cdot 1 & 37 \cdot 0 \\ 18 & 39 \cdot 5 & 28 \cdot 6 & 25 \cdot 2 & 28 \cdot 3 & 16 \cdot 1 & 24 \cdot 6 \\ 23 & 57 \cdot 8 & 33 \cdot 3 & 42 \cdot 0 & 34 \cdot 4 & 34 \cdot 4 & 33 \cdot 2 \\ 26 & 59 \cdot 8 & 24 \cdot 9 & 41 \cdot 9 & 25 \cdot 9 & 29 & 24 \cdot 5 \\ 24 & 27 \cdot 7 & 19 \cdot 8 & 15 \cdot 3 & 18 \cdot 4 & 9 \cdot 1 & 8 \cdot 3\end{array}$

pyloro-duodenal stenosis. Some degree of pyloric obstruction invariably occurs during the active phase of duodenal ulceration, the inflammation and obstruction yielding to conservative measures. As the disease progresses, fibrosis increases and delayed gastric emptying becomes more prominent (Table VI). So not only pyloric scarring, but also oedema, spasm, pyloric incompetence, duodenal cap fibrosis preventing systole, and even food particles lodged intraluminally can delay gastric emptying (Johnson, 1955).

After a few days' conservative treatment, patients with gross pyloric stenosis usually produce large amounts of acid. Evidence exists to suggest that, in patients with pyloric stenosis, the size of the pyloric antrum and the response to histamine may change when the stenosis is treated medically (Capper, Butler, Buckler, and Hallett, 1966). Stomach washouts may reduce gastric stasis, remove residual food with its buffering action, relieve gastritis, and result in a restoration of a hypersecretor state. In three elderly patients, however, the diminution in oxyntic cell activity resulting from prolonged pyloric stenosis was apparently permanent, the histamine 
TABLE VI

TIME OF COMPLETE GASTRIC EMPTYING IN 193 DUODENAL ULCER PATIENTS

\begin{tabular}{|c|c|c|c|c|c|c|}
\hline \multirow{3}{*}{$\begin{array}{l}\text { Length of History since First } \\
\text { Attack }\end{array}$} & \multirow{3}{*}{$\begin{array}{l}\text { No. of Cases } \\
\text { Studied }\end{array}$} & \multicolumn{5}{|c|}{ Time in Hours after Meals } \\
\hline & & Less than 2 & $2-4$ & $4-6$ & $6+$ & $6++$ \\
\hline & & No. & No. & No. & No. & No. \\
\hline Less than 1 year & 16 & $1(6 \cdot 2 \%)$ & $7(43.6 \%)$ & $6(37.5 \%)$ & $2(12.5 \%)$ & $-\quad-$ \\
\hline $1-5$ years & 38 & - - & $12(31.7 \%)$ & $18(47 \cdot 3 \%)$ & $6(15.8 \%)$ & $2(5.2 \%)$ \\
\hline $6-10$ years & 51 & $3(5.9 \%)$ & $22(43 \%)$ & $12(23.5 \%)$ & $10(19 \cdot 6 \%)$ & $4(7.8 \%)$ \\
\hline $11-15$ years & 42 & -1 & $8(19 \%)$ & $16(38 \%)$ & $14(33.3 \%)$ & $4(9.5 \%)$ \\
\hline $16-20$ years & 24 & $-\quad-$ & $6(25 \%)$ & $13(54 \%)$ & $2(8.3 \%)$ & $3(12.5 \%)$ \\
\hline $21-25$ years & 12 & $-\quad-$ & $3(25 \%)$ & $5(41.7 \%)$ & $4(33 \cdot 3 \%)$ & -- \\
\hline More than 25 years & 10 & $-\quad-$ & $1(10 \%)$ & $2(20 \%)$ & $3(30 \%)$ & $4(40 \%)$ \\
\hline Total & 193 & $4(2 \cdot 1 \%)$ & $59(30.5 \%)$ & $72(37.3 \%)$ & $41(21 \cdot 3 \%)$ & $17(8.8 \%)$ \\
\hline
\end{tabular}

response being less than $2 \mathrm{mEq}$. free $\mathrm{HCl} /$ hour. These patients were treated by gastroenterostomy alone (Lewisohn, 1936). Experimentally Milton (1962) has shown that if the outlet of a canine Heidenhain pouch is obstructed, it rapidly loses its ability to respond to histamine stimulation.

The diagnosis of pyloric stenosis is not always easy, sometimes being made for the first time in the operating theatre (Balint and Spence, 1959). The diagnosis of gastric stasis can be even more difficult. We compared the clinical criteria (Roth et al., 1962; Hildebrand and Thomson, 1964) with the estimated gastric emptying times in 193 duodenal and 83 gastric ulcer patients (Tables VII and VIII). We found that, although many of these features are aids to a diagnosis of gastric stasis, none is pathogenic. Emery and Monroe (1931), who found radiological evidence of barium retention in $44 \%$ of duodenal and $50 \%$ of gastric ulcer patients, admitted that in $33 \%$ of cases radiological and clinical studies did not agree in their findings.

Using the tests described, our results showed no evidence for Dragstedt's statement that 'gastric ulcers are usually caused by a hypersecretion of gastric juice of humoral or hormonal origin caused in most patients from stasis of food in the stomach due to vagal hypotonia' (Dragstedt, 1963). Other methods (Oberhelman, 1959) may reveal this stasis, but ours did not. The J-shaped stomach (Carman, 1918) which has long been recognized as a cardinal

TABLE VII

CASE INCIDENCE OF EVIDENCE OF GASTRIC STASIS IN 193 DUODENAL ULCER PATIENTS

\begin{tabular}{|c|c|c|c|c|c|c|c|c|c|c|c|c|c|c|c|c|c|}
\hline \multirow{2}{*}{$\begin{array}{l}\text { Gastric } \\
\text { Empty- } \\
\text { ing Time } \\
\text { (hr.) }\end{array}$} & \multirow{2}{*}{$\begin{array}{l}\text { No. of } \\
\text { Cases } \\
\text { Studied }\end{array}$} & \multirow{2}{*}{$\begin{array}{l}\text { No. } \\
\text { Treated } \\
\text { Medic- } \\
\text { ally }\end{array}$} & \multicolumn{2}{|c|}{$\begin{array}{l}\text { Operative } \\
\text { Stenosis }\end{array}$} & \multicolumn{8}{|c|}{ Symptoms and Signs } & \multirow{2}{*}{$\begin{array}{l}\text { Rest- } \\
\text { ing } \\
\text {-Juice } \\
(>750 \\
\text { ml. })\end{array}$} & \multirow{2}{*}{$\begin{array}{l}\text { Serum } \\
\text { Chlor- } \\
\text { ide } \\
(<85 \\
\text { mEq.|l.) }\end{array}$} & \multicolumn{3}{|c|}{ Radiological } \\
\hline & & & $\begin{array}{l}A b- \\
\text { sent }\end{array}$ & $\begin{array}{l}\text { Pre- } \\
\text { sent }\end{array}$ & $\begin{array}{l}\text { Anor- } \\
\text { exia }\end{array}$ & Nausea & $\begin{array}{l}\text { Recur- } \\
\text { rent } \\
\text { Vomit- } \\
\text { ing }\end{array}$ & Fatigue & $\begin{array}{l}\text { Weight } \\
\text { Loss }\end{array}$ & $\begin{array}{l}\text { Full- } \\
\text { ness }\end{array}$ & $\begin{array}{l}\text { Gastric } \\
\text { Splash }\end{array}$ & $\begin{array}{l}\text { Visible } \\
\text { Perist- } \\
\text { alsis }\end{array}$ & & & $\begin{array}{l}\text { Excess } \\
\text { Rest- } \\
\text { ing } \\
\text { Juice }\end{array}$ & $\begin{array}{l}\text { Gastric } \\
\text { Dil- } \\
\text { atation }\end{array}$ & $\begin{array}{l}\text { Delayed } \\
\text { Empty- } \\
\text { ing }\end{array}$ \\
\hline
\end{tabular}

\begin{tabular}{lrrrrrr}
\hline Less & & & & & \\
than 2 & 4 & 2 & 2 & 0 & 2 & \\
$2-4$ & 59 & 11 & 44 & 4 & 15 & 1 \\
$4-6$ & 72 & 14 & 50 & 8 & 20 & 24 \\
$6+$ & 41 & 7 & 21 & 13 & 12 & 14 \\
$6++$ & 17 & 5 & 1 & 11 & 10 &
\end{tabular}

2
16
19
12

$\begin{array}{rrrr}2 & 0 & 1 & 0 \\ 16 & 0 & 15 & 1 \\ 27 & 3 & 20 & 2 \\ 19 & 0 & 17 & \\ 12 & 0 & 10 & 4\end{array}$

$\begin{array}{lll}0 & 0 & 0 \\ 2 & 0 & 0 \\ 2 & 0 & 0 \\ 1 & 1 & 1 \\ 5 & 1 & 2\end{array}$

$\begin{array}{ll}0 & \\ 0 & 1 \\ 0 & 1 \\ 1 & 1 \\ 1 & \end{array}$

$\begin{array}{rrr}0 & 0 & 0 \\ 10 & 2 & 4 \\ 15 & 5 & 5 \\ 11 & 1 & 5 \\ 7 & 7 & 6\end{array}$

TABLE VIII

CASE INCIDENCE OF EVIDENCE OF GASTRIC STASIS IN 83 GASTRIC ULCER PATIENTS

\begin{tabular}{|c|c|c|c|c|c|c|c|c|c|c|c|c|c|c|c|c|c|}
\hline \multirow{2}{*}{$\begin{array}{l}\text { Gastric } \\
\text { Empty- } \\
\text { ing } \\
\text { Time } \\
\text { (hr.) }\end{array}$} & \multirow{2}{*}{$\begin{array}{l}\text { No. of } \\
\text { Cases } \\
\text { Studied }\end{array}$} & \multirow{2}{*}{$\begin{array}{l}\text { No. } \\
\text { Treated } \\
\text { Medic- } \\
\text { ally }\end{array}$} & \multicolumn{2}{|c|}{$\begin{array}{l}\text { Operative } \\
\text { Stenosis }\end{array}$} & \multicolumn{8}{|c|}{ Symptoms and Signs } & \multirow{2}{*}{$\begin{array}{l}\text { Rest- } \\
\text { ing } \\
(>750 \\
m l .)\end{array}$} & \multirow{2}{*}{$\begin{array}{l}\text { Serum } \\
\text { Chlor- } \\
\text { ide } \\
(<85 \\
\text { mEq./l. })\end{array}$} & \multicolumn{3}{|c|}{ Radiological } \\
\hline & & & $\begin{array}{l}A b- \\
\text { sent }\end{array}$ & $\begin{array}{l}\text { Pre- } \\
\text { sent }\end{array}$ & $\begin{array}{l}\text { Anor- } \\
\text { exia }\end{array}$ & Nausea & $\begin{array}{l}\text { Recur- } \\
\text { rent } \\
\text { Vomit- } \\
\text { ing }\end{array}$ & Fatigue & $\begin{array}{l}\text { Weight } \\
\text { Loss }\end{array}$ & $\begin{array}{l}\text { Full- } \\
\text { ness }\end{array}$ & $\begin{array}{l}\text { Gastric } \\
\text { Splash }\end{array}$ & $\begin{array}{l}\text { Visible } \\
\text { Perist- } \\
\text { alsis }\end{array}$ & & & $\begin{array}{l}\text { Excess } \\
\text { Rest- } \\
\text { ing } \\
\text { Juice }\end{array}$ & $\begin{array}{l}\text { Gastric } \\
\text { Dil- } \\
\text { atation }\end{array}$ & $\begin{array}{l}\text { Delayed } \\
\text { Empty- } \\
\text { ing }\end{array}$ \\
\hline
\end{tabular}

\begin{tabular}{lrrrr}
\hline Less & & & & \\
than 2 & 3 & 0 & 3 & 0 \\
$2-4$ & 19 & 6 & 13 & 0 \\
$4-6$ & 31 & 14 & 17 & 0 \\
6 & 24 & 8 & 16 & 0 \\
$6++$ & 6 & 1 & 2 & 3
\end{tabular}

$\begin{array}{rrrrrr}3 & 1 & 1 & 0 & 2 & 1 \\ 13 & 8 & 8 & 0 & 7 & 2 \\ 14 & 10 . & 9 & 1 & 16 & 5 \\ 11 & 4 & 10 & 0 & 11 & 3 \\ 3 & 2 & 6 & 0 & 5 & 1\end{array}$

0
0
0
0
2

$\begin{array}{llllll}0 & 0 & 0 & 0 & 0 & 0 \\ 0 & 0 & 0 & 1 & 0 & 0 \\ 0 & 0 & 0 & 2 & 1 & 0 \\ 0 & 1 & 0 & 3 & 2 & 1 \\ 0 & 1 & 1 & 4 & 2 & 4\end{array}$


radiological finding in gastric ulceration is not entirely due to the gravitational drag of dense radioopaque barium sulphate. J-shaped stomachs are seen with less dense markers, such as enteric-coated barium, to empty at a normal rate. Burge (1966) believes that the attacks of gastric stasis which lead to gastric ulceration may be too transient to be detected by normal radiological methods. In two patients with gastritis, who subsequently developed gastric ulceration, and in many patients with active gastric ulcers, serial emptying times revealed normal gastric emptying.

In cases of concomitant ulcers, the duodenal usually precedes the gastric, evidence of pyloric stenosis being reported in many instances (Johnson, 1956). We found, like Mangold (1958), that in these cases gastric stasis was unusual, and Salmon (1965) discovered only 11 gastric ulcers in 104 patients with pyloric stenosis. As in other respects (Johnson, et al., 1964), gastric emptying is similar in duodenal and pre-pyloric gastric ulcer patients.

In malignant gastric ulcers, gastric hypochlorhydria was not associated with rapid gastric emptying, the clinical impression of gastric stasis being confirmed (Gilmour, 1958). Apart from one case of adult hypertrophic pyloric stenosis, the coincidence of achlorhydria and an emptying time of over six hours has only been observed pre-operatively in cases of gastric carcinoma. In other parts of the body, stasis is well known as a carcinogenetic factor. A stomach continually exposed to a low titre of carcinogens in food (Doll, 1956) and water (Stocks and Davies, 1960) might develop a malignant growth if the titre of carcinogens was increased (Dungal, 1961) or if gastric emptying were delayed (Capper and Johnson, 1964). The rare gastric carcinoma which follows gastroenterostomy for pyloric stenosis arises usually distal to the anastomosis, where gastric stasis may persist (Wilson, 1960).

After Polya gastrectomy, gastroenterostomy, or any operation where the chyme passes straight into the jejunum, the duodenal braking mechanism is ineffective and the stomach empties more quickly. The gastric remnant after a Polya resection tends to be smaller and empties more quickly than after a Billroth I operation. The size of the gastric remnant probably has more effect on gastric emptying than does the degree of pre-operative stasis (Kraft, Fry, and Weese, 1964).

Studies on patients with gastroenterostomies confirmed previous animal work (Retzer, Morrison, and Harrison, 1960; Armitage and Dean 1963). For adequate gastric emptying, the stoma must be placed in the lower part of the stomach, where the high intragastric pressures develop. One patient, who had a fundic stoma and gastric stasis, was relieved of biliary vomiting by closing his gastroenterostomy. We were unable to relate speed of emptying to the ante- or retro-colic type of anastomosis, or to any particular post-gastroenterostomy symptom.

Pyloroplasty or pylorectomy is often used to cure benign gastric ulcers (Gilchrist, 1956; Farris and Smith, 1961). It is not a drainage operation, however, unless there is actual delayed emptying preoperatively. Except in the one case mentioned, our results agreed with those of Edwards (1961). Animal experiments have shown that reducing outlet resistance, by forming a wide pyloroplasty, results in decreased propulsion by division of the circular antral fibres (Armitage and Dean, 1963). If the function of the pylorus is to prevent regurgitation of chyme when duodenal cap systole occurs, pyloroplasty must cause pyloric incompetence and inefficient propulsion of chyme from the duodenal cap. The effect of destroying the antro-duodenal pressure gradient was shown in dogs in 1937 by Crider and Thomas who placed tubes between the pre-pyloric antrum and the second part of the duodenum.

Gastric stasis has long been recognized as a sequel of vagotomy (Dragstedt et al., 1949). Hunt (1958) showed that the vagus appears to adjust the gastric tone to the volume of the meal ingested, the resulting tension being suitable to initiate peristalsis. Not only is this tone lost, but the peristaltic waves are reduced in force and frequency after vagotomy (Roth et al., 1962). Even when gastric resection or drainage is combined with the vagotomy, gastric emptying is usually biphasic and prolonged. A post-vagotomy emptying time of less than four hours, in the absence of associated gastric resection, strongly suggests incomplete nerve section. No significant difference was found in gastric emptying between cases of complete and selective vagotomy (Table IX).

Gastric stasis has been named as the cause of post-vagotomy diarrhoea, either by causing gastritis and bacterial fermentation in the stomach (Dragstedt and Woodward, 1951) or by overstimulating the gastro-ileo-colic reflex, just as $20 \%$ patients with pyloric stenosis develop diarrhoea (Howe and Spence, 1960). In this series, post-vagotomy diarrhoea was rare, and was not associated invariably with a gross gastric stasis. The figures in Table $\mathrm{X}$ do not represent a true incidence for this series as several patients were included in these post-operative studies who had had surgery at other hospitals.

Post-vagotomy gastric ulcer is now fortunately rare due to the addition of adequate drainage. Of 197 patients treated by vagotomy alone, seven 

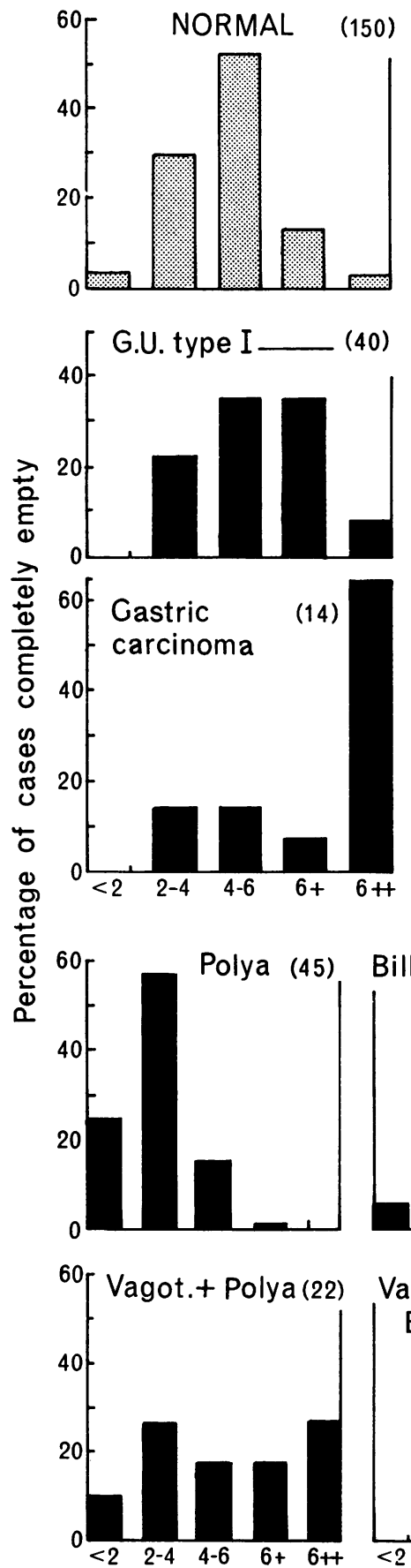

Duodenal Ulcer_(193)

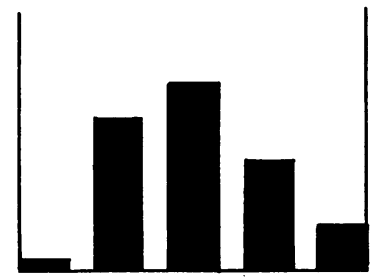

G.U. type I+D.U.

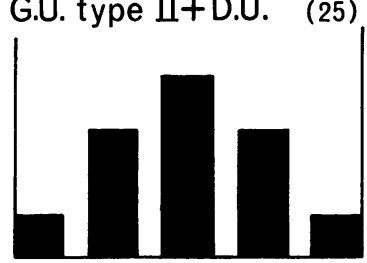

Pernicious anaemia

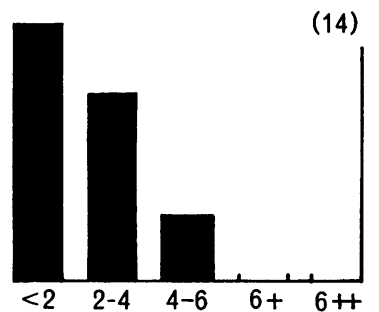

Gastric Ulcer (83)

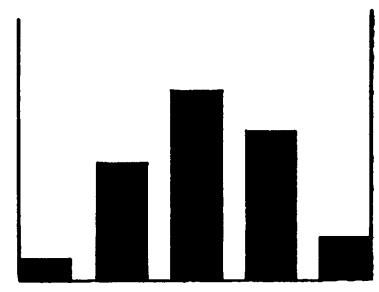

G.U. type III (18)

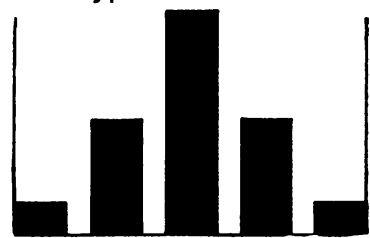

Hiatus hernia (12)

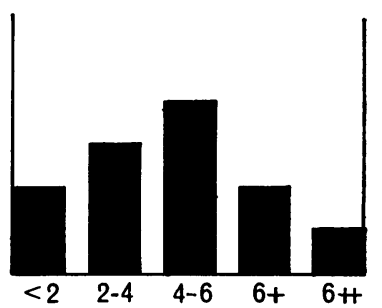

(7) Gastroenterostomy
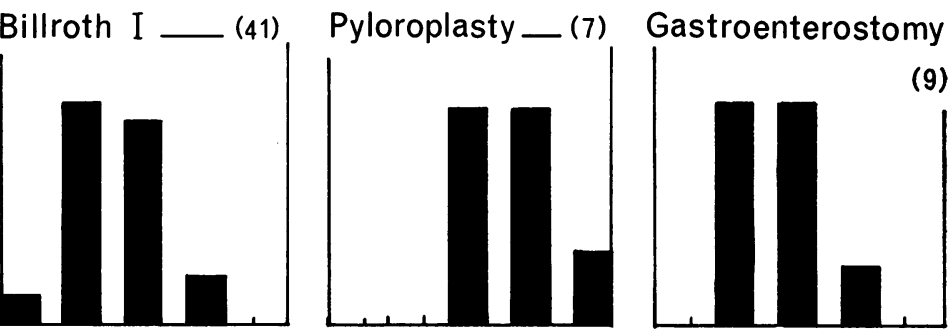

(9)
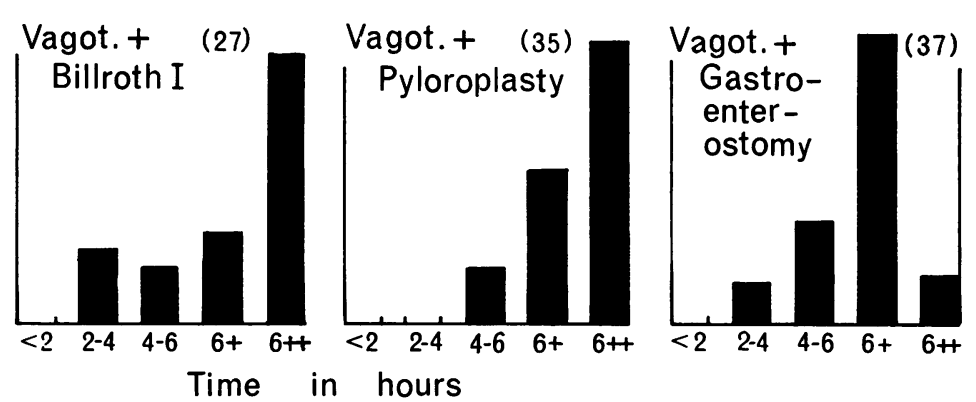

FIG. 2. Illustrations of time of complete gastric emptying in the conditions described. Figures in brackets denote numbers of cases. 


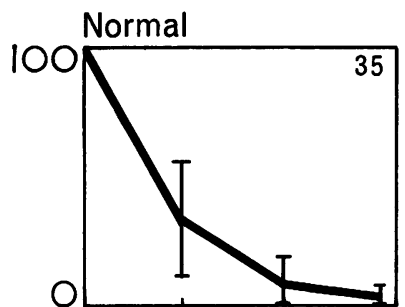

G.U. type I

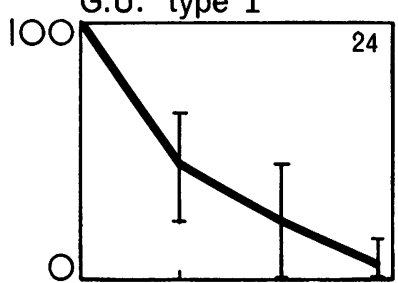

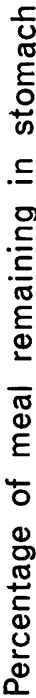
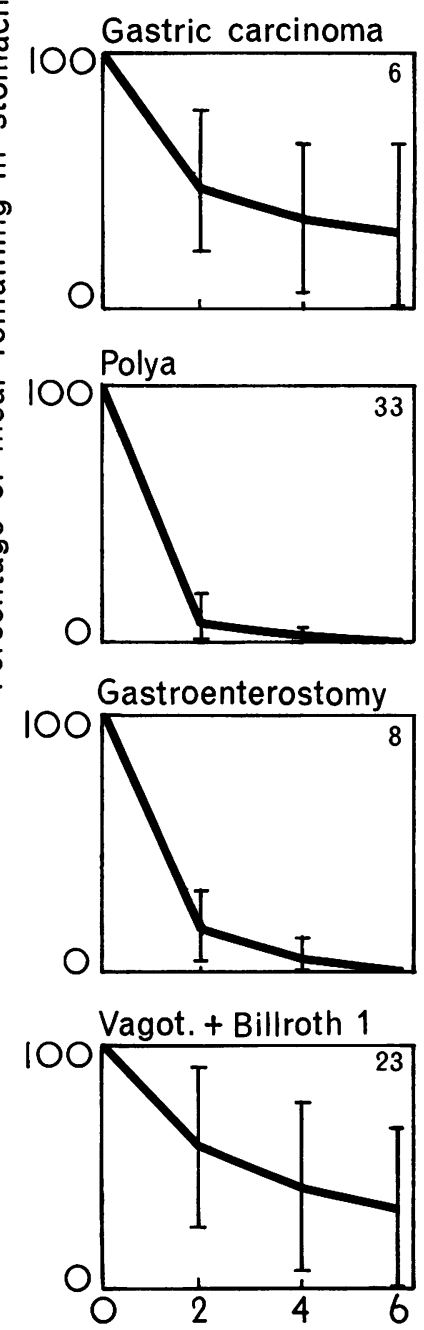

D.U.

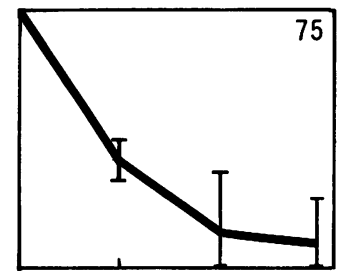

G.U. type II

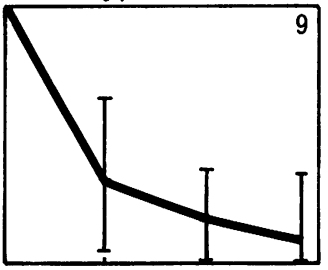

Pernicious anaemia

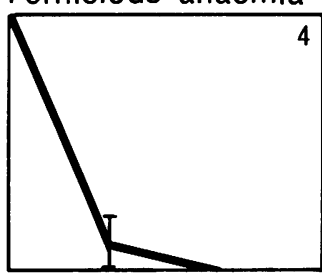

Billroth 1

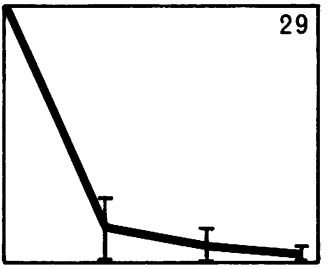

Vagotomy + Polya

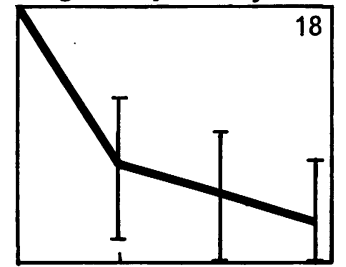

Vagot.+ Pyloroplasty

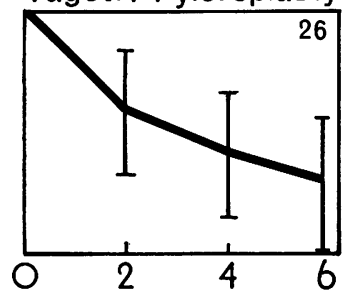

FIG. 3. Illustrations of the rate of gastric emptying in the cases described studied radiologically.

The graphs show means and standard deviations of the percentage of meal remaining in the stomach at two, four, six or eight hours after the meal. Figures inside squares denote numbers of cases.

G.U. type III

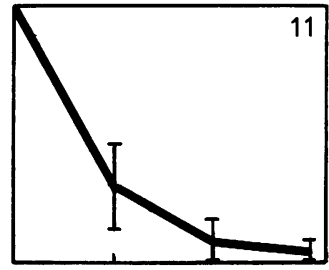

Hiatus Hernia

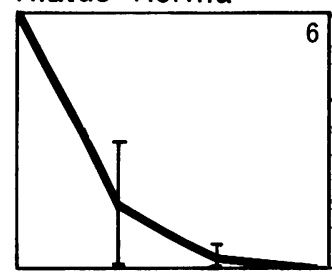

Pyloroplasty

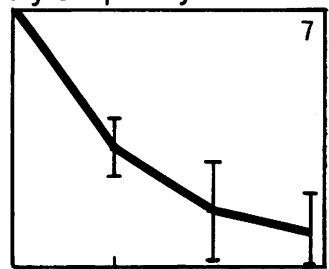

Vagotomy

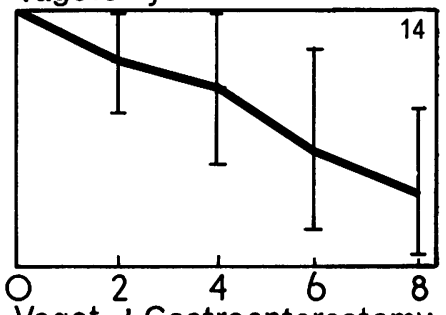

Vagot. +Gastroenterostomy

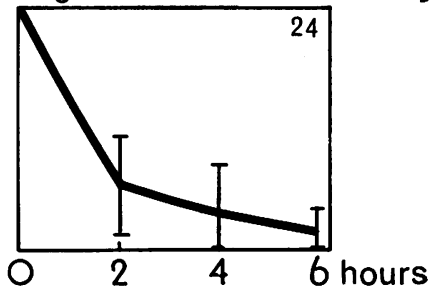


TABLE IX

TIME OF COMPLETE GASTRIC EMPTYING AFTER VAGOTOMY AND DRAINAGE ${ }^{1}$

\begin{tabular}{|c|c|c|c|c|c|c|}
\hline \multirow[t]{3}{*}{ Type of Vagotomy } & \multirow{3}{*}{$\begin{array}{l}\text { No. of Cases } \\
\text { Studied }\end{array}$} & \multicolumn{5}{|c|}{ Time in Hours after Meal } \\
\hline & & Less than 2 & $2-4$ & $4-6$ & $6+$ & $6++$ \\
\hline & & No. & No. & No. & No. & No. \\
\hline Total anterior + total posterior & 78 & - & $5(6.4 \%)$ & $14(17.9 \%)$ & $28(35.9 \%)$ & $31(39 \cdot 7 \%)$ \\
\hline Total anterior + selective posterior & 12 & - & $2(17 \cdot 7 \%)$ & $1(8.3 \%)$ & $6(50 \%)$ & $3(25 \%)$ \\
\hline Selective anterior + total posterior & 4 & - & - & - & $1(25 \%)$ & $3(75 \%)$ \\
\hline Selective anterior + selective posterior & 5 & - & - & - & $3(60 \%)$ & $2(40 \%)$ \\
\hline Total & 99 & - & $7(7 \cdot 1 \%)$ & $15(15 \cdot 2 \%)$ & $38(38.4 \%)$ & $39(39.4 \%)$ \\
\hline
\end{tabular}

${ }^{1}$ Gastroenterostomy, pyloroplasty or antrectomy-Billroth I.

TABLE $\mathrm{X}$

TIME OF COMPLETE GASTRIC EMPTYING AFTER VAGOTOMY

Incidence of Diarrhoea

\begin{tabular}{|c|c|c|c|c|c|}
\hline \multirow{3}{*}{$\begin{array}{l}\text { No. of Cases } \\
\text { Studied }\end{array}$} & \multicolumn{5}{|c|}{ Time in Hours after Meal } \\
\hline & Less than 2 & $2-4$ & $4-6$ & $6+$ & $6++$ \\
\hline & No. & No. & No. & No. & No. \\
\hline $\begin{array}{r}86 \\
29 \\
6\end{array}$ & $\begin{array}{l}2(2 \cdot 3 \%) \\
-\end{array}$ & $\begin{array}{r}10(11.6 \%) \\
2(6.9 \%) \\
1(16.7 \%)\end{array}$ & $\begin{array}{l}16(18.6 \%) \\
3(10.4 \%) \\
-\end{array}$ & $\begin{array}{r}27(32.1 \%) \\
13(44.8 \%) \\
2(33.3 \%)\end{array}$ & $\begin{array}{c}31(36.0 \%) \\
11(37.9 \%) \\
3(50 \%)\end{array}$ \\
\hline 121 & $2(1 \cdot 7 \%)$ & $13(10.7 \%)$ & $19(15.7 \%)$ & $42(34 \cdot 7 \%)$ & $45(37 \cdot 2 \%)$ \\
\hline
\end{tabular}

SUMMARY

developed gastric ulcers (Dragstedt and Woodward, 1963). Yet of five gastric ulcers treated by vagotomy alone, three healed (Harper and Dragstedt, (1947).

In the majority of reported cases of vagotomy and antrectomy a gastrojejunal-Polya-anastomosis was used (Palumbo, Sharpe, Lulu, Bloom and Porter, 1962; Roth et al., 1962; Edwards, Edwards, Sawyers, Gobbel, Herrington and Scott, 1963) rather than the gastro-duodenal-Billroth I-anastomosis. After a Polya reconstruction, the food empties more normally, bypassing the duodenum with its specialized absorptive and sensory mucosa (Butler, 1961).

When a 'drainage' operation is added to a vagotomy, care must be taken that the drainage is adequate (Woodward, 1958; Burge, 1960b).

The operation of vagotomy and pyloroplasty is now widely used in the treatment of duodenal ulcer (Burge, 1960a, Weinberg, 1963), gastric ulcer (Hendry, 1961; Farris and Smith, 1963; Burge, 1966) and concomitant gastric and duodenal ulcers (Dragstedt and Woodward, 1963). The reported effects of this operation on gastric emptying vary considerably. Food dumping too fast is recorded (Moore, 1963). Some find no delay in gastric emptying (British Medical Journal, 1958), others report $6 \%$ (Davies, 1956) or $28 \%$ (Bergin and Jordan, 1959) cases of gastric stasis. Our series suggests that this operation, which heals the widest variety of ulcers, causes marked delay in gastric emptying. We have no experience of pyloromyotomy as an adjunct to vagotomy, but Hopton and Torrance (1966) state that it does not provide adequate drainage after vagotomy.

The significance of alterations in gastric emptying is stated. Two methods suitable for out-patient studies are described. The results obtained by these methods in 150 normal, 280 peptic ulcer, and 239 postoperative patients are recorded. On the basis that they represent the normal passage of food in representative groups of patients, their significance may be summarized: (1) The pattern of gastric emptying in the stomach of the normal and uncomplicated gastro-duodenal ulcer patient is similar. (2) There is no evidence that gastric stasis accompanies gastric ulceration. (3) Gastric stasis may be associated with gastric carcinoma. (4) The effect of different gastric operations is recorded: gastric resection speeds emptying of the gastric remnant; bypassing the duodenal circuit speeds gastric emptying; vagotomy, with or without drainage, delays gastric emptying.

I wish to thank Mr. W. M. Capper, Mr. T. J. Butler, and Dr. R. J. Vecht for assistance. I also wish to acknowledge with gratitude a grant from the Medical Research Council.

\section{REFERENCES}

Abbott, W. E., Krieger, H., and Levey, S. (1958). Technical surgical factors which enhance or minimize postgastrectomy abnormalities. Ann. Surg., 148, 567-593.

Armitage, A. K., and Dean, A. C. B. (1963). Function of the pylorus and pyloric antrum in gastric emptying. Gut, 4, 174-178.

Balint, J. A., and Spence, M. P. (1959). Pyloric stenosis. Brit. med. J., 1, 890-894.

Bergin, W. F., and Jordan, P. H., Jr. (1959). Gastric atonia and delayed gastric emptying after vagotomy for obstructing ulcer. Amer. J. Surg., 98, 612-616.

Brit. med. J. (1958). Vagotomy in treatment of duodenal ulcer. (Leading article). 1, 631-632. 
Burge, H. W. (1960a). Vagal nerve section in chronic duodenal ulceration. Ann. roy. Coll. Surg. Engl., 26, 231-244.

(1960b). Vagotomy in the treatment of peptic ulceration. Postgrad. med. J., 36, 2-12.

- (1966). The aetiology of benign lesser curve gastric ulcer: vagotomy and pyloroplasty in its treatment. Ann. roy. Coll. Surg. Engl., 38, 349-369.

Butler, T. J. (1961). The effect of gastrectomy on pancreatic secretion in man. Ann. roy. Coll. Surg. Engl., 29, 300-327.

- (1964). Personal communication.

Capper, W. M., and Johnson, H. D. (1964). Vagotomy and carcinoma of the stomach. Lancet, 2, 1063-1064.

_- Butler, T. J., Buckler, K. G., and Hallett, C. P. (1966). Variation in size of the gastric antrum. Ann. Surg., 163, 281-290.

Carman, R. D. (1918). Roentgen diagnosis of concurrent gastric and duodenal ulcer. Amer. J. Roentgenol., 4, 552-554.

Crider, J. O., and Thomas, J. E. (1937). A study of gastric emptying with the pylorus open. Amer. J. dig. Dis., 4, 295-300.

Davies, J. A. L. (1956). Late results of vagotomy combined with gastrojejunostomy or pyloroplasty in the treatment of duodenal ulceration. Brit. med. J., 2, 1086-1091.

Doll, R. (1956). Environmental factors in the aetiology of cancer of the stomach. Gastroenterologia (Basel), 86, 320-328.

Dragstedt, L. R. (1963). A guide for the surgical treatment of peptic ulcer. Amer. J. Surg., 105. 239-294.

- Camp, E. H., and Fritz, J. M. (1949). Recurrence of gastric ulcer after complete vagotomy. Ann. Surg., 130, 843-854. and Woodward, E. R. (1951). Appraisal of vagotomy for peptic ulcer after seven years. J. Amer. med. Ass., 145, 795-802. (1963). Coexistent duodenal and gastric ulcers treated by vagotomy and pyloroplasty. J. Amer. med. Ass., 184, 1014-1017.

Dungel, N. (1961). The special problem of stomach cancer in Iceland J. Amer. med. Ass., 178, 789-798.

Edwards, D. A. W. (1961). Physiological concepts of the pylorus. Proc. roy. Soc. Med., 54, 930-933.

Edwards, L. W., Edwards, W. H., Sawyers, J. L., Gobbel, W. G., Jr., Herrington, J. L., Jr., and Scott, H. W., Jr. (1963). The surgical treatment of duodenal ulcer by vagotomy and antral resection. Amer. J. Surg., 105, 352-360.

Emery, E. S. and Monroe, R. T. (1931). Peptic ulcer-the diagnostic value of roentgen ray before and after treatment. Amer. $J$. Roentgenol, 25, 51-64.

Enriquez de Salamanca, F. (1943). La fisiología gástrica humana según los datos de mi procedimiento de exploración functional. Rev. Clin. esp., 8, 94-104.

Farris, J. M., and Smith, G. K. (1961). Role of pyloroplasty in the surgical treatment of gastric ulcer. Ann. Surg., 154, Suppl., 293-297.

- - - (1963). Treatment of gastric ulcer (in situ) by vagotomy and pyloroplasty. Ann. Surg., 158, 461-480.

Gilchrist, R. K. (1956). Surgical treatment of high-lying gastric ulcer. J. Amer. med. Ass., 162, 1039-1041.

Gilmour, J. (1958). Clinical aspects of carcinoma of stomach in diagnosis. Brit. med. J., 1, 745-748.

Goodall, P. (1964). Early gastroduodenal motility following operation. Brit. J. Surg., 51, 864-867.

- (1966). Personal communication.

Griffith, G. H., Owen, G. M., Kirkman, S., and Shields, R. (1966). Measurement of rate of gastric emptying using Chromium-51. Lancet, 1, 1244-1245.

Harper, P. V., Jr., and Dragstedt, L. R. (1947). Section of the vagus nerve to the stomach in the treatment of benign gastric ulcer. Arch. Surg., 55, 141-150.

Hendry, W. G. (1961). The treatment of peptic ulceration by vagotomy and Finney pyloroplasty. Postgrad. med. J., 37, 137-146.

Hertz, A. F. (1913). The cause and treatment of certain unfavorable after-effects of gastro-enterostomy. Ann. Surg., 58, 466-472.

Hildebrand, H., and Thomson, F. B. (1964). Stasis gastric ulcer-a complication of duodenal ulcer. Canad. med. Ass. J., 90, 915-919.

Hopton, D. S., and Torrance, H. B. (1966). Vagotomy and pyloromyotomy in the treatment of duodenal ulcer. Brit. J. Surg., $53,757-758$.

Horton, R. E., Ross, F. G. M., and Darling, G. H. (1965). Determination of the emptying-time of the stomach by use of entericcoated barium granules. Brit. med. J., 1, 1537-1539.

Hosford, J. (1949). Somes aspects of partial gastoectomy. Ibid., 1, 929-932.
Howe, C. T., and Spence, M. P. (1960). Pyloric stenosis in adults. Postgrad. med. J., 36, 743-748.

Hunt, J. N. (1957). Influence of hydrochloric acid on gastric secretion and emptying in patients with duodenal ulcer. Brit. med. J., 1, 681-684.

(1958). The regulation of gastric emptying. In Modern Trends in Gastroenterology (2nd series). Edited by F. Avery Jones, pp. 163-176. Butterworth, London.

- (1959). Gastric emptying and secretion in man. Physiol. Rev., 39, 491-533.

and Spurrell, J. (1951). The pattern of emptying of the human stomach. J. Physiol. (Lond.), 113, 157-168.

Johnson, H. D. (1954). Postgastrectomy syndromes. Postgrad. med. J., 30, 154-159.

- (1955). The special significance of concomitant gastric and duodenal ulcers. Lancet, 1, 266-270.

- (1956). Associated gastric and duodenal ulcers. Surg. Gynec. Obstet., 102, 287-292.

- (1961). The pylorus: its function and some surgical considerations. Proc. roy. Soc. Med., 54, 938-940.

—, Love, A. H. G., Rogers, N. C., and Wyatt, A. P. (1964). Gastric ulcers, blood groups and acid secretion. Gut, 5, 402-411.

Kraft, R. O., Fry, W. J., and D. Weese, M. S. 1964. Postvagotomy gastric atony. Arch. Surg., 88, 865-874.

Lewisohn, R. (1936). The complications of gastro-enterostomy. Surg. Clin. N. Amer., 16, 805-824.

Mangold, R. (1958). Combined gastric and duodenal ulceration. Brit. med. J., 2, 1193-1197.

Milton, G. W. (1962). The behaviour of gastric epithelium under various circumstances. Ann. roy. Coll. Surg. Engl., 30, 351-367.

Mix, C. L. (1922). 'Dumping stomach' following gastrojejunostomy. Surg. Clin. N. Amer., 2, 617-622.

Moore, F. D. (1963). Surgery in search of a rationale. Eighty years of ulcerogenic surgery. Amer. J. Surg., 105, 304-312.

Oberhelman, H. A., Jr. (1959). Measurement of gastric emptying by motor meal. In The Physiology and Treatment of Peptic Ulcer. edited by J. Garrott Allen, pp. 93-95. University of Chicago Press, Chicago.

Palumbo, L. T., Sharpe, W. S., Lulu, D. J., Bloom, M. H., and Porter, H. R. (1962). Results in 300 cases of antrectomy with bilateral vagotomy for chronic duodenal ulcer. Surgery, 51, 289-294.

Retzer, O., Morrison, M., and Harrison, R. C. (1960). The effect of gastroenterostomy on gastric secretion. Surg. Gynec. Obstet., 111, 285-288.

Roth, J. L. A., Vilardell, F., and Affolter, H. (1962). Postvagotomy gastric stasis. Ann. N.Y. Acad. Sci., 99, 203-212.

Rothnie, N. G., Harper, R. A. K., and Catchpole, B. N. (1963). Early post-operative gastrointestinal activity. Lancet, 2, 64-67.

Salmon, G. B. (1965). Personal communication.

Shay, H., and Gershon-Cohen, J. (1934). Experimental studies in gastric physiology in man. II. A study of pyloric control. The roles of acid and alkali. Surg. Gynec. Obstet., 58, 935-955.

Silverio, J. (1964). Gastric emptying time in the newborn and the nursling. Amer. J. med. Sci., 247, 732-738.

Snell, A. M. (1937). Behavior of stomach after operation for duodenal ulcer. Amer. J. Surg., 35, 45-55.

Stocks, P., and Davies, R. I. (1960). Investigation of a localised high incidence of gastric cancer. Publ. Hlth. (Lond.), 74, 404-412.

Sun, D. C. H., Shay, H., and Woloshin, H. J. (1959). Effect of Tricyclamol on gastric emptying and intestinal function. Amer. J. dig. Dis., 4, 282-288.

Thomas, J. E. (1957). Mechanics and regulation of gastric emptying Physiol. Rev., 37, 453-474.

Todd, T. W., and Kuenzel, W. (1929). Studies in alimentary tract of man. 1. The attainment of reliability of gastric responses. J. Lab. clin. Med., 14, 1017-1032.

Van Liere, E. J., and Sleeth, C. K. (1940). The emptying time of the normal human stomach as influenced by acid and alkali with a review of the literature. Amer. J. dig. Dis., 7, 118-1231.

Weinberg, J. A. (1963). Vagotomy and pyloroplasty in the treatment of duodenal ulcer. Amer. J. Surg., 105, 347-351.

Wells, C., Tinckler, L., Rawlinson, K., Jones, H., and Saunders, J. (1964). Post operative gastrointestinal motility. Lancet, 1, 4-10.

Wilson, T. I. (1960). Carcinoma of the stomach after gastroenterostomy. J. roy. Coll. Surg. Edinb., 5, 235.

Woodward, E. R. (1958). Hyperfunction of gastric antrum following vagotomy and pyloroplasty. Arch. Surg., 77, 289-293. 